\title{
КОРЕЛАЦИЈАТА ПОМЕЃУ КЕП ИНДЕКСОТ НА 12-ГОДИШНИ ДЕЦА И КОНЦЕНТРАЦИЈАТА НА ФЛУОРОТ ВО ВОДАТА ЗА ПИЕЬЕ ОД ЈУГОИСТОЧНИОТ РЕГИОН НА РЕПУБЛИКА МАКЕДОНИЈА
}

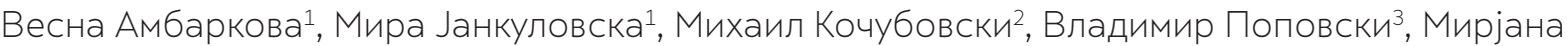 \\ Поповска ${ }^{4}$

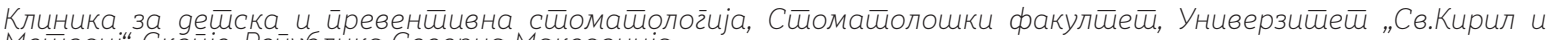 \\ мейоguj", Скойје, Рейублика Северна Макеgонија \\ Инсйитиуй за јавно зяравје на Рейублика Северна Макеgонија, Скойје, Реӣублика Северна Макеgонија

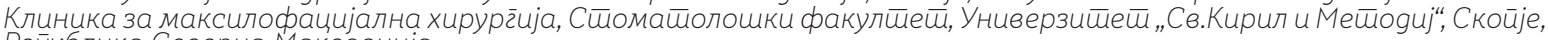 \\ Рейублика Северна Макеgонија

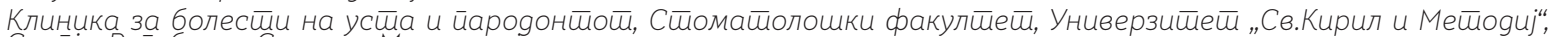 \\ Скойје, Рейублика Северна Макеgонија
}

\begin{abstract}
Цитирање: Амбаркова В, Јанкуловска М, Кочубовски М. Поповски В, Поповска М. Корелацијата помеѓ КЕП индексот на 12-годишни деца и концентрацијата на флуорот во водата за пиење од центрацијата на флуорот во водата за пиење од
Југоисточниот регион на Република Македонија. Арх J Здравје 2019;11(1):58-67

Клучни зборови: дентален кариес, школски деца, вода за пиење, флуор, КЕП индекс, орална епидемиологија

*Кореспонденција: Весна Амбаркова, Клиника за детска и превентивна стоматологија, Стоматолошки факултет, Универзитет „Св.Кирил и Методиј“ Cкопје, E-mail: ambveki@yahoo.com

Примено: 10-дек-2018; Ревидирано: 15-јан-2018; Прифатено: 28-фев-2019; Објавено: 30-сеп-2019

Печатарски права: 2019 Весна Амбаркова. Оваа статија е со отворен пристап дистрибуирана под условите на нелокализирана лиценца, која овозможува неограничена употреба, дистрибуција и репродукција на било кој медиум, доколку се цит раат оригиналниот(ите) автор(и) и изворот.

Конкурентски интереси: Авторот изјавува дека

\section{Извадок}

Целта на оваа студија беше да се утврди корелацијата помеѓ КЕП (Кариес, Екстракција, Пломба) индексот на 12-годишни деца и концентрацијата на флуорот во водата за пиење од населените места каде што децата живеат. Материјал и методи: Во испитувањето беа опфатени 129 ученици од 2 централни и 2 подрачни основни училишта, на кои им се одреди КЕП индексот. Децата живеат во градот Струмица и 3 различни села. Деветнаесет примероци на вода беа земени од испитуваната област за да се одреди концентрацијата на флуор со помош на електрохемиски метод користејќи го јонометарот (pH/ISE meter-Thermo-Orion) со специјална Ф-електрода (Thermo Orion Ion Plus Fluoride Electrode) на Институтот за јавно здравје. За одредување на корелацијата помеѓу одредените варијабли беше користен Spearman-овиот метод. Резултати: Вкупниот број деца во испитуваниот примерок изнесуваше 129, од кои 59 (45,7\%) беа од женски и 70 (54,3\%) од машки пол. Просечниот КЕП индекс кај оваа група деца изнесуваше 1,94, со стандардна девијација од „2,5. Максимални концентрации на флуор во водата за пиење од 1,36 ppmF беа утврдени во селото Банско и од 0,36 ppmF во селото Муртино, додека минимални (0,08 ppmF) во градот Струмица. Корелацијата помеѓ вредноста на КЕП индексот кај децата на возраст од 12 години од Југоисточниот регион и концентрацијата на флуорот во водата за пиење постоеше негативна, индиректна корелација, со вредност на коефициентот r =-0,16. Заклучок: Корелацијата помеѓ КЕП индексот и концентрацијата на водата за пиење е негативна, индиректна корелација, и оваа корелација е статистички значајна ( $<<0,05)$.

\section{PUBLIC HEALTH}

\section{THE CORRELATION BETWEEN THE DMFT OF THE 12-YEAR-OLD CHIL- DREN AND THE CONCENTRATION OF FLUORINE IN DRINKING WATER FROM THE SOUTHEAST REGION OF THE REPUBLIC OF MACEDONIA}

\begin{abstract}
Vesna Ambarkova ${ }^{1}$, Mira Jankulovska ${ }^{1}$, Mihail Kochubovski² ${ }^{2}$ Vladimir Popovski ${ }^{3}$, Mirjana Popovska ${ }^{4}$

Department for preventive and pediatric dentistry. Faculty of Dental Medicine, University Ss.Cyril \& Methodius, Skopje, Republic of North Macedonia

Institute of Public Health of North Macedonia, Skopje, Republic of North Macedonia

Clinic of Maxillofacial surgery, University Clinic Center "Mother Theresa", Skopje, Republic of North Macedonia

Department of oral pathology and periodontology, Faculty of Dental Medicine, University Ss.Cyril \& Methodius, Skopje, Republic of North Macedonia.
\end{abstract}

Citation: Ambarkova V, Jankulovska M, Kochubovsk M, Popovski V, Popovska M.The correlation between the DMFT of the 12-year-old children and the concentration of fluorine in drinking water from the Southeast region of the Republic of Macedonia. Arch Pub Health 2019; 11 (1): 58-67 (Macedonian)

Key words: dental caries, school children, drinking water, fluoride, DMFT index, oral epidemiology

*Correspondence: Vesna Ambarkova, Department for children and preventive dental medicine, Faculty of Dental Medicine, Ss. Cyril and Methodius University Skopje, Republic of North Macedonia. E-mail: ambveki@yahoo.com Received: 10-Dec-2018; Revised: 15-Jan-2019 Accepted: 28-Feb-2019; Published: 15-Mar-2019

Copyright: ${ }^{\bullet 2019}$. Vesna Ambarkova. This is an open-access article distributed under the terms of the Creativ Commons Attribution License, which permits unrestric ed use, distribution, and reproduction in any medium provided the original author(s) and source are credited.

Competing Interests: The author have declared that no competing interests

\section{Abstract}

The aim of this study was to determine the correlation between the DMFT (Decayed, Missing, Filling Teeth) index of 12-year-old children from the Southeast region of R. Macedonia and the concentration of fluorine in drinking water from the populated areas where children live. Material and methods: A total of 129 children from 2 central and 2 regional primary schools were enrolled in the examination, and the DMFT index was determined in these children. Thev live in 2 different cities and 2 different villages. Four water samples were taken from the examined area to determine the fluorine concentration by the electrochemical method using the $\mathrm{pH}$ / ISE meter-Thermo-Orion with a special F-electrode (Thermo Orion Ion Plus Fluoride Electrode) at the Institute for Public Health. Spearman's method was used to determine the correlation between the specified variables. Results: The total number of children in the examined sample was 129, of whom 70 (54.3\%) were male and 59 (45.7\%) were female. The average DMFT index in this group of children was 1.94, with a standard deviation of \pm 2.5 . Maximum concentration of fluorine in drinking water of $1.36 \mathrm{ppmF}$ was determined in the village Bansko, and $0.36 \mathrm{ppmF}$ in the village Murtino, while the minimum (0.08 ppmF) in the city of Strumica. Correlation of the DMFT index in 12-year-old children from the Southeast region and the concentration of fluorine in the drinking water had a negative, indirect correlation, with the value of the coefficient $r=-0.1655$. Conclusion: The correlation between the DMFT index and the concentration of drinking water is a negative, indirect correlation, and statistically, this correlation is highly significant $(p<0.05)$. 


\section{Вовед}

Југоисточниот регион е еден од осумте статистички и плански региони на Македонија. Овој регион граничи со Вардарскиот и Источниот регион. Регионот ги опфаќа Струмичко-Радовишката и Гевгелиско-Валандовската котлина, односно сливното подрачје на Струмичката река и долното сливно подрачје на реката Вардар. Неговата површина е 2.739 квадратни километри или $11 \%$ од територијата на Република Македонија. Во овој регион се наоѓаат десет општини. Во 2011, 8,4\% од населението на Република Македонија живее во овој регион. Густината на популацијата изнесува 63,2 луѓе на км², а важи за добро развиен регион во нашата држава каде стапката на невработеност изнесува само ${ }^{9,31}$.

Во Југоисточниот регион, според пописот од 2002 година, живеат 171.416 граѓани или 8,47\% од вкупното население на Република Македонија. Во овој регион водоснабдувањето го вршат јавните претпријатија: Претпријатие за комунални дејности -Богданци, ЈКП „Комунален сервис” - Валандово, ЈКП „Комуналец”- Гевгелија, ЈКП „Комуналец” - Полин- Стар Дојран, ЈП „Прогрес” - Радовиш, ЈКП „Комуналец “- - Струмица.

Во подрачјето на општината Струмица постојат 25 села. Селата Баница и Габрово се приклучени на водовод од 2011 година, селата Горни Балдовци од март 2010, додека селата Банско, Дабиле, Добрејци, Куклиш, Муртино и Сачево од 2009 година. Во 2008 година на водоводна мрежа беа приклучени селата Свидовица, Просениково, а во 2006 година селото Водоча. Селата Вељуса и Костурино сѐ уште не се приклучени на водоводна мрежа ${ }^{2}$.

Постојат недоволни податоци за состојбата на денталниот кариес во Република Македонија. Тие се објавуваат спорадично и неконтинуирано. Нечева Љ и сор. преку проектот „Процена на оралното здравје и потребен третман кај населението на СФРЈ, со примена на базичните критериуми и иницијатива на С3О“ спроведен во 1991 година утврдиле КЕП вредност кај 12-годишни деца од 3,48 во Велес и 6,55 во Скопје ${ }^{3}$.
Амбаркова во своето истражување утврдила просечен КЕП индекс од 3,47 кај 12-годишни деца од Источниот регион на трајните заби ${ }^{4}$ Во 2013 година Амбаркова и сор. спровеле епидемиолошка студија кај 15-годишни средношколци од две средни училишта од градот Струмица и добиле просечен КЕП индекс од 3,55 кај овие испитаници нѐ поттикна да ја преземеме оваа студија со цел да ја утврдиме распространетоста на забен кариес кај 12-годишни деца од Југоисточниот регион, како и да ја одредиме корелацијата помеѓу КЕП индексот и концентрацијата на флуорот во водата за пиење од овој регион.

\section{Материјал и методи}

Клиничкото испитување се состоеше од одредување на КЕП индексот кај 12- годишни деца во согласност со базичните критериуми за процена на оралното и денталното здравје и со потребите за санација што ги препорачува Светската здравствена организација (C3O, 2013). Проценката на интензитетот на забниот кариес ја направивме според општоприфатениот Klein - Palmer-ов индекс „КЕП“, кој претставува збир на кариозни, пломбирани и екстрахирани заби. Прегледите ги изведоа двајца доктори стоматолози во согласност со препораките кои произлегуваат од базичните критериуми за проценка на оралното и денталното здравје што ги препорачува С3О 6 .

Учениците на 12-годишна возраст кои беа опфатени во испитувањето беа од следните основни училишта од источниот регион: подрачно основно училиште „Маршал Тито“ - Банско, ОУ „Маршал Тито“ - Муртино, подрачно ОУ „Маршал Тито“ - Сачево, ОУ „Сандо Масев“ - Струмица. Кај сите испитаници на возраст од 12 години беа направени стандардни стоматолошки систематски прегледи со сонда и огледалце.

За лабораториското испитување се служевме со земање примероци на вода од сите урбани и рурални населени места во кои живеат испитуваните деца од Југоисточниот регион на Република Македонија и се детерминираше концентрацијата на флуорот во нив. Во на- 
шето испитување беше користена електрохемиската постапка на одредување на концентрацијата на флуоридите со јон-селективна електрода.

Главен дел на јон-селективната електрода е мембраната од лантанов флуорид. Кога мембраната е во контакт со растворот кој содржи флуориди (во овој случај водата), се мери разликата на потенцијалот. Тој потенцијал зависи од количеството на слободни флуоридни јони и е опишан со Нернстовата формула:

$$
\mathrm{E}=\mathrm{Eo}-\mathrm{C} \log \mathrm{A}
$$

\section{E - $\quad$ измерен потенцијал на електро} дата

Ео - референтен потенцијал (константа)

A - количеството на флуоридот во растворот

C - наклон на електродата

Примероците беа собирани во полиетиленски садови од 100 мл со капаче кое имаше навои. Мерењето се вршеше веднаш штом примероците на вода пристигнуваа во лабораторијата. По протресување на шишето со вода, по 1 мл од секој примерок се зема и се меша со 0,1 мл Total Strength Adjusting Buffer. $\mathrm{KoH}^{-}$ центрацијата на флуорот на сите примероци беше одредувана со користење на јон-селективна електрода (Thermo Orion Ion Plus Fluoride Electrode) и јонометар
(pH/ISE meter- Thermo-Orion) на Институтот за јавно здравје. За хемиска анализа се користеше 10\% TISAB Aluminon. Флуоридни стандарди со концентрација од 0,01 до 1,00 мг/л беа користени за калибрирање на мерењата.

Пред да се започне со мерењето на количеството на флуоридите, потребно е да се извршат некои подготовки за да се провери исправноста на мерниот инструмент и наклонот на електродата. Тоа се прави според упатствата на производителот. Кога инструментот е подготвен, мерењето може да започне.

\section{Резултати}

Децата на возраст од 12 години од Југоисточниот регион во ова истражување се претставени со примерок од 129 испитаници, од кои 70 (54,3\%) од машки пол и 59 (45,7\%) од женски пол (табела 1). Во однос на националната припадност, 112 (86,8\%) беа Македонци, а останатите 17 (13,2\%) беа испитаници од ромска националност. Нема голема разлика во местото на живеење, односно од град (Струмица) се 48,8\% деца, во рурално подрачје живеат 51,2\% деца од оваа група испитаници, и тоа $21,7 \%$ се од село Муртино, 27,1\% од село Банско и 2,3\% деца се со место на живеење во село Сачево (табела 1).

Табела 1. Дистрибуција на испитаниците во однос на пол, националност и место на живеење

\begin{tabular}{|l|c|c|}
\hline & $\mathbf{N}$ & $\%$ \\
\hline Пол на испитаниците & & \\
\hline Машки & 70 & $54,26 \%$ \\
\hline Женски & 59 & $45,74 \%$ \\
\hline Националност & & \\
\hline Македонци & 112 & $86,82 \%$ \\
\hline Роми & 17 & $13,18 \%$ \\
\hline Место на живеење & 63 & \\
\hline Град & 66 & $48,84 \%$ \\
\hline Село & & $51,16 \%$ \\
\hline Име на град / село & 63 & \\
\hline Струмица & 28 & $21,71 \%$ \\
\hline Муртино & 35 & $27,13 \%$ \\
\hline Банско & 3 & $2,32 \%$ \\
\hline Сачево & & \\
\hline
\end{tabular}




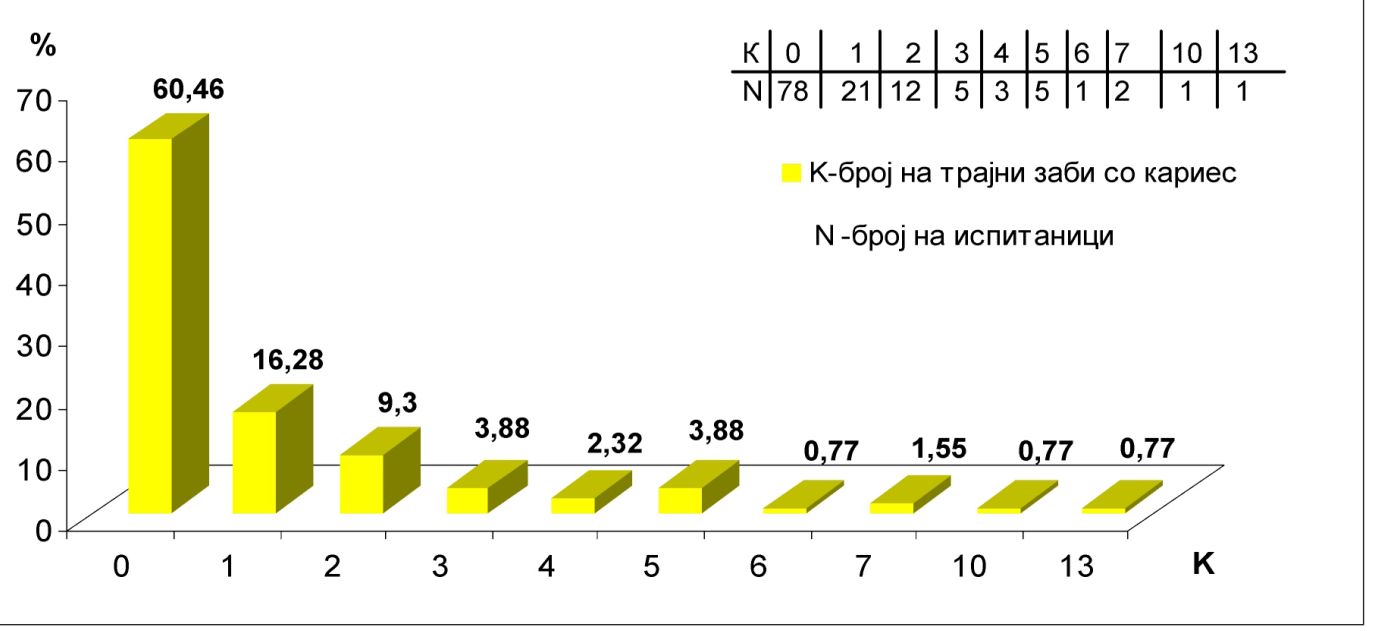

Графикон 1. Дистрибуција на испитаници во однос на број на кариозни трајни заби

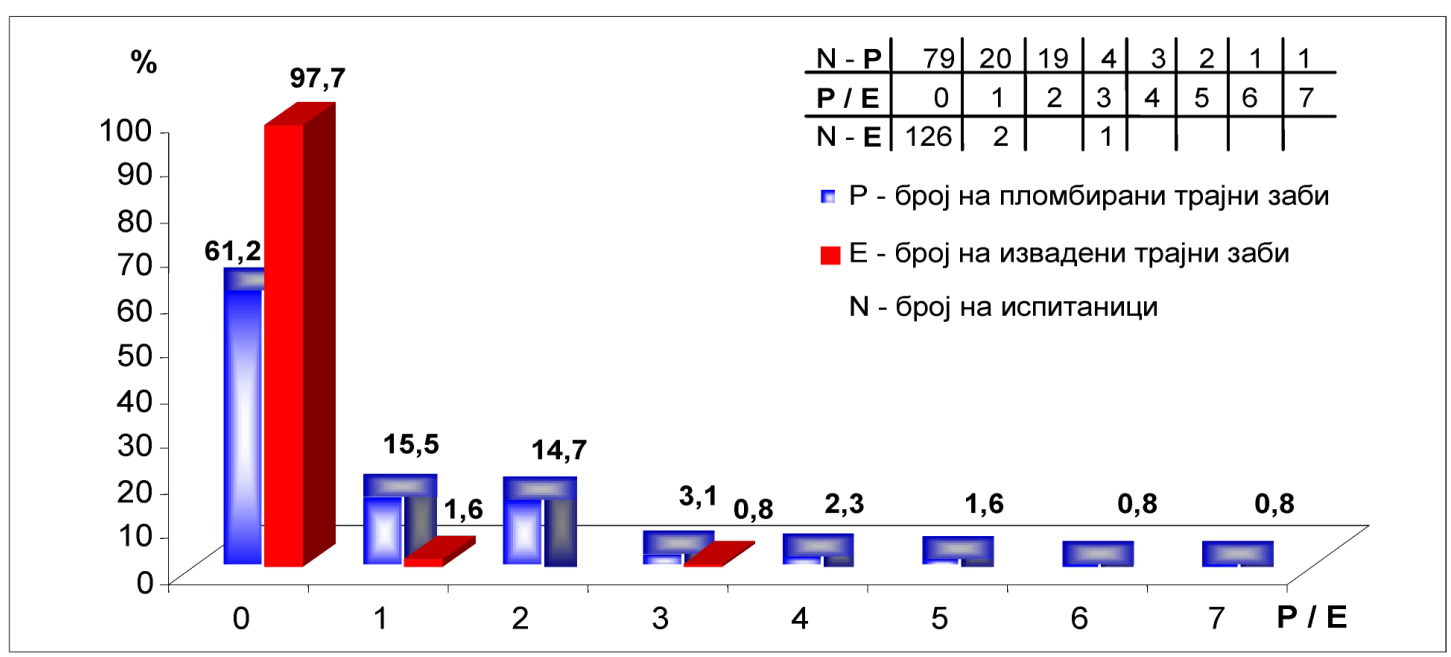

Графикон 2. Дистрибуција на испитаници во однос на број на пломбирани и извадени трајни заби

Табела 2. Дистрибуција на кариозни, извадени и на реставрирани трајни заби во однос на пол

\begin{tabular}{|c|c|c|}
\hline & \multicolumn{2}{|c|}{$\overline{\text { пол }}$} \\
\hline & машки (n \%) & женски (n \%) \\
\hline \multicolumn{3}{|c|}{ К - кариес на трајни заби } \\
\hline нема & 70 & $54,26 \%$ \\
\hline има & 59 & $45,74 \%$ \\
\hline \multicolumn{3}{|c|}{ Pearson Chi-square: $0,014 \quad \mathrm{df}=1 \mathrm{p}=0,91$} \\
\hline \multicolumn{3}{|c|}{\begin{tabular}{|l|l} 
E - извадени трајни заби & \\
\end{tabular}} \\
\hline нема & 112 & $86,82 \%$ \\
\hline има & $1(1,43 \%)$ & $2(3,39 \%)$ \\
\hline \multicolumn{3}{|c|}{ Pearson Chi-square: $0,54 \mathrm{df}=1 \mathrm{p}=0,46$} \\
\hline \multicolumn{3}{|c|}{ П - пломбирани трајни заби } \\
\hline нема & 63 & $48,84 \%$ \\
\hline има & 66 & $51,16 \%$ \\
\hline Pearsc & $<0,05$ & \\
\hline
\end{tabular}


На графиконите 1 и 2 прикажана е дистрибуцијата на застапеноста на кариозни, извадени и пломбирани трајни заби во групата деца на возраст од 12 години од Југоисточниот регион. Седумдесет и осум (60,5\%) испитаници немаа кариес , додека во групата од 51 (39,5\%) со кариозни трајни заби беа најголемиот број деца со кариес на еден заб - 21 (16,3\%). Кај 3 (2,3\%) деца од оваа група беше извршена екстракција на заби, и тоа, кај едно дете екстракција на 3 заба. Без пломбирани заби беа 79 (61,2\%) деца, додека во групата со реставрирани заби, 20 (15,5\%) испитаници имаа еден реставриран заб, 19 (14,7\%) 2 реставрирани заби.

Минималниот број кариозни, извадени и пломбирани трајни заби во групата 12-годишни деца од Југоисточниот регион изнесува 1, додека максималниот број кариозни заби е 13, максималниот број извадени заби е 3, максималниот, пак, број на реставрирани заби е 7. Пресметаната средна вредност, односно медијана, покажува дека половина испитаници од овој примерок имаа кариес на повеќе од 2 заба, имаа екстракција на повеќе од еден заб, и имаа пломбирано повеќе од 2 заба.

Вредноста на КЕП индексот на трајните заби во групата 12-годишни деца од Југоисточниот региот се движеше во ранг од 0 до 13, и просечно изнесуваше 1,94 $\pm 2,5$.

Дистрибуцијата на кариозни, извадени и пломбирани заби, во зависност од полот на испитаниците на возраст од 12 години од Југоисточниот регион презентирана е во табела 4. Кариес на трајните заби почесто имаа машките деца (40\% наспроти
38,98\%); извадени заби почесто беа регистрирани кај женските испитаници (3,39\% наспроти $1,43 \%)$, тие исто така почесто од машките имаа пломбирани заби (49,15\% наспроти 30\%). Тестираните разлики во бројот на кариозни, извадени и пломбирани заби, во зависност од полот на испитаниците од оваа група, покажуваат статистичка сигнификантност единствено во дистрибуцијата на реставрираните заби $(\mathrm{p}=0,03)$. Во Југоисточниот регион, женските деца на возраст од 12 години, значително почесто од машките имаат стоматолошка интервенција за реставрирање на забите. Полот на испитаниците на 12-годишна возраст од Југоисточниот регион нема сигнификантно влијание врз вредноста на КЕП индексот ( $=0,35)$.

Просечната вредност на индексот во групата испитаници од машки пол изнесува $1,66 \pm 2,14$, додека во групата испитаници од женски пол КЕП индексот има просечна вредност од 2,27 $\pm 2,85$.

Во табела 3 прикажана е дистрибуцијата на кариозни, извадени и пломбирани заби во зависност од местото на живеење (град или село) на испитаниците на возраст од 12 години од Југоисточниот регион. Резултатите покажуваат дека кариес значително почесто $(\mathrm{p}=0,03)$ се регистрира кај децата од руралните подрачја на овој регион (48,48\% наспроти 30,16\%). Екстракција на заби се регистрира само во групата деца кои живеат во село - 4,55\%, додека пломбирани заби почесто имаат децата од град (39,68\% наспроти 37,88\%), но оваа разлика не е статистичка сигнификантна $(\mathrm{p}=0,83)$.

Табела 2. Дистрибуција на кариозни, извадени и на реставрирани трајни заби во однос на пол

\begin{tabular}{|c|c|c|}
\hline \multirow[t]{2}{*}{ Варијабла -град/село } & \multicolumn{2}{|c|}{ пол } \\
\hline & град & село \\
\hline \multicolumn{3}{|l|}{ К - кариес на трајни заби } \\
\hline нема & $44(69,84 \%)$ & $34(51,52 \%)$ \\
\hline има & $19(30,16 \%)$ & $32(48,48 \%)$ \\
\hline \multicolumn{3}{|c|}{ Pearson Chi-square: $4,53 \mathrm{df}=1 \mathrm{p}=0,03^{*} \mathrm{p}<0,05$} \\
\hline \multicolumn{3}{|l|}{ Е - извадени трајни заби } \\
\hline нема & $63(100 \%)$ & $63(95,45 \%)$ \\
\hline има & 0 & $3(4,55 \%)$ \\
\hline \multicolumn{3}{|l|}{ Pearson Chi-square: $2,93 \mathrm{df}=1 \quad \mathrm{p}=0,087$} \\
\hline \multicolumn{3}{|l|}{ П - пломбирани трајни заби } \\
\hline нема & $38(60,32 \%)$ & $41(62,12 \%)$ \\
\hline има & $25(39,68 \%)$ & $25(37,88 \%)$ \\
\hline
\end{tabular}

Pearson Chi-square: $0,04 \mathrm{df}=1 \quad \mathrm{p}=0,83$ 
Табела 4. Дистрибуција на кариозни, извадени и пломбирани трајни заби во Струмица, Муртино, Банско и Сачево

\begin{tabular}{|c|c|c|c|c|}
\hline \multirow{2}{*}{$\begin{array}{l}\text { Варијабла } \\
\text { град/село }\end{array}$} & \multicolumn{4}{|c|}{ Име на град/село } \\
\hline & Струмица & Муртино & Банско & $\overline{\text { Сачево }}$ \\
\hline \multicolumn{5}{|c|}{ К - кариес на трајни заби } \\
\hline нема & $44(69,84 \%)$ & $11(39,29 \%)$ & $22(62,86 \%)$ & $1(33,33 \%)$ \\
\hline има & $19(30,16 \%)$ & $17(60,71 \%)$ & $13(37,14 \%)$ & $2(66,67 \%)$ \\
\hline \multicolumn{5}{|c|}{ Pearson Chi-square: $0,014 \quad \mathrm{df}=1 \mathrm{p}=0,91$} \\
\hline \multicolumn{5}{|c|}{ Е - извадени трајни заби } \\
\hline нема & $63(100 \%)$ & $26(92,86 \%)$ & $34(97,14 \%)$ & $3(100 \%)$ \\
\hline има & 0 & $2(7,14 \%)$ & $1(2,86 \%)$ & 0 \\
\hline \multicolumn{5}{|c|}{ Pearson Chi-square: $0,54 \mathrm{df}=1 \mathrm{p}=0,46$} \\
\hline \multicolumn{5}{|c|}{ П - пломбирани трајни заби } \\
\hline нема & $38(60,32 \%)$ & $14(50 \%)$ & $25(71,43 \%)$ & $2(66,67 \%)$ \\
\hline има & $25(39,68 \%)$ & $14(50 \%)$ & $10(28,57 \%)$ & $1(33,33 \%)$ \\
\hline
\end{tabular}

Табела 5 ја прикажува дистрибуцијата на кариозни, извадени и реставрирани заби кај децата на возраст од 12 години од градот Струмица и руралните општини Муртино, Банско и Сачево.

Вредноста на КЕП индексот не зависи сигнификантно од местото на живеење на испитаниците на возраст од 12 години од Југоисточниот регион ( $\mathrm{p}=0,08)$. Во групата деца од град просечната вредност на КЕП индексот изнесува $1,44 \pm 2,08$, додека во групата деца кои живеат во село, КЕП индексот има просечна вредност од $2,41 \pm 2,77$.

Во табелата 6 прикажани се просечните вредности на концентрацијата на флуор во водата за пиење во однос на местото на земање на примерокот вода.

Анализираната корелација помеѓу вредноста на КЕП индексот, како зависна варијабла, и концентрацијата на флуор во водата за пиење, прикажана е на графикон 3. Вредноста на коефициенот $\mathrm{R}=$ - 0,167 покажува дека помеѓу овие две варијабли постои негативна, односно индиректна корелација. Тоа значи дека со зголемување на концентрацијата на флуор во водата, вредноста на индексот опаѓа, и обратно, помали вредности на КЕП индексот се добиваат ако концентрацијата на флуор во водата за пиење е поголема. За $\mathrm{p}<0,05$ и статистички оваа корелација е сигнификантна, односно значајна.

Табела 5. Дескриптивна статистика на КЕП индекс на трајни заби / Струмица, Муртино, Банско и Сачево /

\begin{tabular}{|l|c|c|c|c|c|c|}
\hline \multicolumn{6}{|l}{ Дескриптивна статистика- КЕП (индекс на трајни заби) } \\
\hline $\begin{array}{c}\text { Варијабла } \\
\text { град/село }\end{array}$ & $\mathrm{N}$ & mean \pm SD & $\begin{array}{c}95 \% \text { confi- } \\
\text { dence interval } \\
\text { of means }\end{array}$ & min-max & median & $\begin{array}{c}\text { lower -upper } \\
\text { quartiles }\end{array}$ \\
\hline Струмица & 63 & $1,44 \pm 2,08$ & $0,92-1,97$ & $0-13,0$ & 1,0 & $0,0-2,0$ \\
\hline Муртино & 28 & $3,64 \pm 3,23$ & $2,39-4,89$ & $0-12,0$ & 2,5 & $1,0-5,5$ \\
\hline Банско & 35 & $1,37 \pm 1,88$ & $0,73-2,02$ & $0-7,0$ & 0,0 & $0,0-3,0$ \\
\hline Сачево & 3 & $3,0 \pm 2,64$ & $-3,57-9,57$ & $0-5,0$ & 4,0 & $0,0-5,0$ \\
\hline
\end{tabular}


Табела 6. Дескриптивна статистика на КЕП индекс на трајни заби / Струмица, Муртино, Банско и Сачево /

\begin{tabular}{|c|c|}
\hline Место на живеење & Концентрација на Ф во вода \\
\hline Струмица & 0,0810 \\
\hline Муртино & 0,3820 \\
\hline Банско & 1,3600 \\
\hline
\end{tabular}

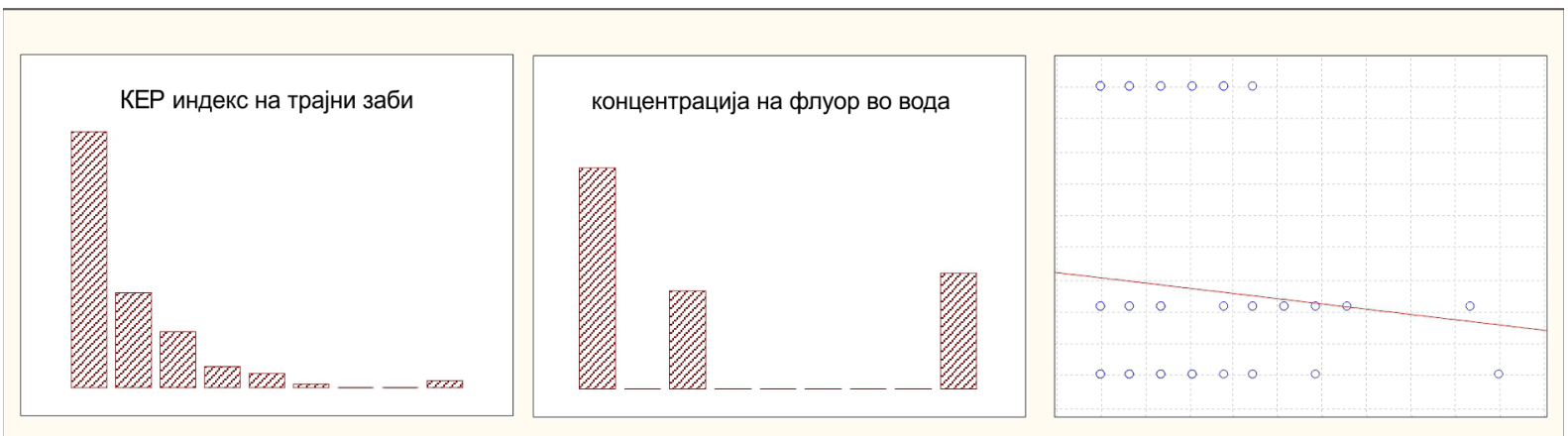

Spearman Rank Order Correlations $\mathrm{R}=-0,1655 \mathrm{p}<0,05$

Графикон 3. Корелација - КЕП индекс на трајните заби / концентрација на флуор во водата

\section{Дискусија}

Резултатите за состојбата на оралното здравје и потребите од санација на населението од нашата држава, добиени од епидемиолошката студија во 1991 год. изработена во рамките на заедничката југословенска студија „Процена на оралното здравје и потребен третман кај населенето на СФРЈ, со примена на базичните критериуми и иницијатива на C30“, укажуваат на многу сериозна состојба. КЕП индексот се движел од 0,54 кај шестгодишните деца до 23,84 кај популацијата од 65 години. Во оваа студија предводена од Нечева, а спроведена во градовите Скопје, Велес, Штип и Охрид, биле опфатени 1.034 испитаници од рурална и урбана средина на возраст од 6, 12, 15, 18, 35-44 и преку 65 години од целата држава. Просечниот КЕП индекс кај трајната дентиција на 12-годишните деца во 1991 година изнесувал 3,48 во Велес и 6,55 во Скопје ${ }^{3}$.

Во својата студија, Давидовиќ и сор. ја испитувале состојбата на оралното здравје кај 599 ученици од 6- и 12-годишна возраст од источните градови на P. Српска и утврдиле вредност на просечниот КЕП индекс од 2,6 кај 6-годишните деца и 5,5 кај 12-годишните деца7.
Ѓорѓев и сор. извршиле систематски прегледи на основните параметри од нутритивниот статус и од стоматолошкиот статус (дентален кариес и дентална флуороза) кај 76 училишни деца. Кај дел од испитаните деца (тест група), кои од раѓањето пиеле вода со средна содржина на флуор од 2,71 mg/L (с. Тромеѓe), просечниот КЕП индекс на трајните заби бил многу низок и изнесувал 0,56, но кај повеќето имало флуороза помеѓу I и II степен („благ“ и „многу благ“). Кај другите деца (контролна група), кои од раѓањето пиеле вода која содржела флуор помалку од 0,5 mg/L (с. Старо Нагоричане), просечниот КЕП индекс изнесувал 3,09, додека појавата на забна флуороза изостанала. Не била утврдена разлика во нутритивниот статус помеѓу двете групи8. Денес во селото Тромеѓе е постигната оптимизација на содржината на флуоридите на околу $1 \mathrm{mg} / \mathrm{L}$, благодарение на мешањето на водата од новоизградениот селски водовод со водата од градскиот водовод во Куманово, која содржи флуориди во количество од околу 0,1-0,2 mg/L.

Со цел да се подобри оралното здравје во Република Македонија, донесена е Националната стратегија за превенција 
од орални заболувања кај децата од 0-14 години, во периодот од 2008-20189. Во неа како примарни превентивни мерки се опфатени механичката и хемиската контрола на денталниот плак, егзо- и ендогената примена на флуоридите, контролираното внесување на шеќери, редовната нега на забите, употребата на забен конец, залевањето на фисурите и јамичките, едукацијата и мотивацијата за одржување на оралното здравје. Во имплементацијата на оваа програма, како стручни кадри за нејзиното спроведување се вклучени сите специјалисти по детска и превентивна стоматологија, општи стоматолози кои се вработени во државниот сектор во превентивната стоматологија, воспитувачите во детските градинки и наставниот кадар во училиштата.

Во друга студија спроведена во Италија, просечната вредност на КЕП индексот изнесувал $(1,1)\left({ }^{10}\right)$. Исто така, во Јужна Африка како земја во развој, просечната вредност на КЕП индексот кај деца на 12-годишна возраст изнесувал $1,1^{11}$.

Во Јордан, просечниот КЕП индекс кај децата на 12-годишна возраст бил 2,512, а кај кувајтските ученици 2, $6^{13}$ и, конечно во Сирија, просечниот КЕП индекс се движел од 1,4 до 2,5 за истата возраст во 2004 година ${ }^{14}$. Во Израел просечниот КЕП индекс изнесувал 1,66 ${ }^{15}$.

Во 1980 година, Светската здравствена организација оформи глобална Светска кариес скор мапа (банка на податоци) за оралното здравје кај деца на 12 години за 107 од вкупно 173 држави. Од нив, 51\% имале просечен КЕП индекс од 3,0 или помал, додека останатите 49\% имале повисоки вредности. Во 2000 година, Банката располагала со податоци од 184 земји, од кои 68\% имаат просечен КЕП индекс помал од $3^{16}$. Што се однесува до Нигерија, како земја во развој, било утврдено дека 85\% од 12-годишните ученици биле без кариес ${ }^{17}$.

Во земјите со релативно низок КЕП индекс кај 12-годишните деца, 65\% од децата имаат искусено забен кариес на своите трајни заби. Од скандинавските земји, Англија и Холандија се единствените земји кај кои околу половина од 12-годишните деца немаат кариес. Поголемиот дел од земјите на ЕУ имаат просечен КЕП индекс под 3,0 кај децата на 12-годишна возраст. Деветте земји кои имаа просечен КЕП индекс над 3,0 се: Австрија, Исланд, Германија, Грција, Израел, Шпанија, Југославија, Унгарија4,3 и Полска 5,1. Балтичките земји, како Латвија, на пр., има високо ниво на просечен КЕП индекс 7,7. Показател за неспособноста на актуелните стоматолошки служби да се справат со проблемот на забниот кариес е релативно високиот процент на нетретирани кариес лезии. Процентот на нетретирани кариозни лезии кај децата од 12-годишна возраст изнесува 29\% во Франција, 45\% во Велика Британија, 46\% во Унгарија, а 53\% во Полска ${ }^{18,19,20}$. Тозија и сор. во својата пилот-студија, спроведена во 1994 година, утврдиле фреквенција на несаниран кариес кај учениците (од прво, трето, петто и седмо одделение и први и четврти клас од средното образование) од 38,8\%; кариес преваленцијата се движела од 90,9\% во петто одделение до 100\% во први клас. Учениците на возраст од 12 години во истата студија имале умерено висок кариес индекс (просек 4,2) 21.

Во Р. Македонија постои несоодветен систем за следење и регистрирање на забниот кариес, чија статистика не е усогласена со онаа на Европската Унија и СЗО; постојните законски обврски не се почитуваат и затоа не постојат релевантни статистички индикатори $(\text { DMFT })^{22,23}$.

Според резултатите кои ги добивме, децата на 12-годишна возраст од Југоисточниот регион имаат ниска преваленција на кариес. Во нашето претходно испитување кое го спроведовме кај истата возраст на деца од Вардарскиот регион, корелацијата помеѓу КЕП индексот и концентрацијата на флуор во водата за пиење исто така беше негативна, индирекна корелација, која беше високо сигнификантна ${ }^{24}$. Подобрата состојба на оралното здравје кај 12 годишните деца од Југоисточниот регион во однос на истиот од Вардарскиот ${ }^{24}$ и Источниот $^{25}$, се должи на подобрата социо-економска состојба на овој регион во однос на останатите, како и на поголемиот стадард на населението кое живее во овој регион. Тоа што е неопходно да се направи за во иднина да добиваме 
уште подобри резултати за состојбата на оралното здравје кај сите деца од Република Македонија е промовирање на оралното здравје, континуирано спроведување на петте превентивни мерки од Националната стратегија. Секако неопходно е да се спроведе дигитализација на евиденцијата и регистрацијата на кариесот, екстракцијата и пломбирањето, за да може полесно и побрзо да го пресметаме КЕП индексот, да го споредиме со КЕП индексот на децата од останатите регионаи, како и да ги следиме и обработуваме промените кои ќе се случуваат од година во година, а соодветно на тие промени и да реаѓираме.

\section{Референци:}

1. Регионите во Република Македонија, Државен завод за статистика на Република Македонија, 2017. Достапно на: www.stat.gov.mk

2. Амбаркова В. Компаративна студија помеѓу оралното здравје и природно флуорираните води за пиење во одредени региони на Република Македонија. [Докторска дисертација]. Скопје: Стоматолошки факултет, Универзитет „Св.Кирил и Методиј“. 2015.

3. Нечева Љ, Царчев М, Накова М, Димитровски В, Зужелова М, Ѓоргова J, Дејаноски К, Беќировиќ M, Гиговски Н. Состојбата на оралното здравје и потребната санација на населението од Македонија по региони. Макед Стоматол Прегл 1993; 17(2):89-95.

4. Ambarkova V, Ivanova V. Dental Caries Experience among primary school children in the Eastern Region of the Republic of Macedonia. Oral Health Dent Manag. 2014; 13(1) : 514-520.

5. Ambarkova V, Panova O. Dental Caries Experience among 15-years OldChildren in the SoutheastRegion of the Republic of Macedonia. Oral Health Dent Manag. 2015; 14(6): 353360.
6. Oral Health Surveys, Basic Methods 5 -th Edition, World Health Organization, Geneva, 2013.

7. Davidović B, Janković S, Ivanović D. Procjena uticaja promocije oralnog zdravja u djece istočnog djela Republike Srpske. Biomedicinska istraživanja 2011;2(1):11-19.

8. Ѓорѓев Д, Нечева Љ, Фиљански П, Колевска Л, Пасху М, Царчев M, Доцевска В. Некои аспекти на нутритивниот и стоматолошкиот статус кај школски деца во ендемско-флуоротични зони во СР Македонија.Мак.Мед. Преглед, 1989, 3-4, 83-85.

9. Национална стратегија за превенција на оралните заболувања кај деца од 0-14 години, во периодот од 2008-2018 година. Министерство за здравство. Република Македонија. Скопје, 2007.

10 Gampus G, Solinas G, Mattill, Castiglia B. Caries experience in 12year-old: the Italian national path finder on children's oral health. Caries Res 2006; 40: 331.

11 Van Wyk PJ, Louw AJ, du Plessis JP. Caries status and treatment of the 1999 - 2002 National Children's Oral Health Survey. SADJ. 2004 Jul; 59 (6): 238, 240 - 2.

12. Albashaireh Z, Al- Hadi Hamash A. Prevalence of Dental caries in12-13 year-old-Jordanian students. SADJ 2002; 57(3):89-91.

13. Al-Mutwa SA, Shyama M, AlDuwairi Y, Soparker P. Dental caries experience of Kuwaiti school children. Community Dent Health 2006; 23(1):31-6.

14. Beiruti N.van Palenstein Helderman WH.. Oral health in Syria. Int Dent J. 2004 Dec;54(6 Suppl 1):383-8.

15. Zusman SP, Ramon T, Natopov L, Kooby E. Dental health of 12-yearold in Israel - 2002. Community Dent Health. 2005 Sep; 22 (3): 175 - 9.

16. WHO WHO Oral Health Country/ Area Profile Programme. http:// 
www.whocollab.od.mah.se/index. html, 1999.

17. Denloye O, Ajayi D, Bankole O. A study of dental caries prevalence in 12 - 14 year old school children in Ibadan, Nigeria. Pediatric Dental Journal 15 (2): 147 - 151, 2005

18. Pitts NB, Palmer J. The Dental Caries Experience of 5-, 12- and 14-Year Old Children in Great Britain. Surveys Coordinated by the Br. Association for the Study of Community Dentistry in 1991/92, 1992/93 and 1990/91.Community Dent. Health 1997; 11: 42 \pm 52 .

19. Pitts NB, Evans DJ. The Total Dental Caries Experience of 5 Year-Old Children in the United Kingdom. Community Dent. Health 1997; 14: 47-52.

20. Pitts NB, Evans DJ, Nugent ZJ. The Total Dental Caries Experience of 12-Year-Old Children in the United Kingdom. Surveys Coordinated by the Br. Association for the Study of Community Dentistry in 1996/7. Community Dent. Health 1998; 15: $49 \pm 54$.

21. Тозија $Ф$, Панева Љ, Чкалеска Д, Георгиев 3, Кипровски М. Фреквенцијата на кариесот кај училишните деца и младината во Р. Македонија и негова превенција. Макед Стоматол Прегл 1994; 18(3-4):128-33.

22. Ќосевска E и сор. Здравјето и здравствената заштита на населението во Р.Македонија. ЈЗУ Институт за јавно здравје на Република Македонија. Скопје, 2011.

23. Здравје за сите во 21 век. Светска здравствена канцеларија. Регионална канцеларија за Европа, 1999:56-1.

24. Амбаркова В. Корелација помеѓу КЕП индексот на 12-годишните деца и концентрацијата на флуорот во водата за пиење од Вардарскиот регион на Република Македонија. Архиви на јавно здравје 2018; 10(2):5-13

25. Ambarkova V. Ivanova V. Dental
Caries Experience among primary school children in the Eastern Region of the Republic of Macedonia. Oral Health Dent Manag. 2014; 13 March (1) : 514-520 